\title{
A retrospective analysis of the effects of adopting individual transferable quotas in the Tasmanian red rock lobster, Jasus edwardsii, fishery
}

\author{
Katell G. Hamon ${ }^{1,2,3,4,5, a}$, Olivier Thébaud ${ }^{1,2}$, Stewart Frusher ${ }^{5}$ and L. Richard Little 3,6 \\ 1 IFREMER, UMR AMURE, Département d'économie maritime, BP 70, 29280 Plouzané, France \\ 2 Université européenne de Bretagne, Université de Brest, UMR AMURE, IUEM, 12 rue de Kergoat, CS 93837, 29238 Brest Cedex 3, France \\ 3 CSIRO, Marine and Atmospheric Research, GPO Box 1538, Hobart, Tasmania 7001, Australia \\ 4 University of Tasmania, School of Zoology, GPO Box 252-05, Hobart, Tasmania 7001, Australia \\ 5 Tasmania Aquaculture and Fisheries Institute, University of Tasmania, Marine Research Laboratories, Nubeena Crescent Taroona, \\ GPO Box 252-49, Hobart, Tasmania 7001, Australia \\ ${ }^{6}$ Crawford School of Economics and Government, Australian National University, Canberra, ACT 0200, Australia
}

Received 22 December 2008; Accepted 15 July 2009

\begin{abstract}
Individual transferable quotas (ITQ) were implemented in the Tasmanian red rock lobster fishery in 1998 and ten years later we assessed the impacts on the fishery. Particular attention was devoted to investigating the performances of the fishery with regard to three features identified as major impacts in the literature: rationalization of the fishing fleet, change in fishing strategy in order to maximise the fisher's profit and concentration of fishing rights and activity. On average, the fishery reacted as expected and reached its objective in terms of reconstruction of the biomass, but the overall assessment in terms of resulting profitability is not very conclusive. There is no evidence of decrease of the profitability over the period of the study but the fishery is more reactive to external factors on its export market in China than to changes in its own structure.
\end{abstract}

Key words: ITQ / Economic effects / Red rock lobster fishery / Jasus edwardsii / Australia

\begin{abstract}
Résumé - En 1998, les quotas individuels transférables ont été mis en place dans la pêcherie de langouste rouge de Tasmanie et dix ans plus tard, nous avons évalué leur impact sur la pêcherie. Nous avons accordé une importance particulière à l'étude des performances de la pêcherie au niveau de trois caractéristiques, identifiées par une recherche bibliographique, comme des effets majeurs de ces quotas individuels transférables : rationalisation de la flottille de pêche, changements dans les stratégies de pêche afin de maximiser le profit des pêcheurs et concentration des droits et de l'activité de pêche. En moyenne, la pêcherie a réagi conformément aux prévisions et a atteint ses objectifs en terme de reconstruction de la biomasse ; cependant, le bilan global en terme de profitabilité est mitigé. Il n'y a pas de signe de diminution de la profitabilité au cours de la période étudiée mais la pêcherie est plus réactive aux stimulus externes sur son marché d'exportation, la Chine, qu'aux changements survenus dans sa propre structure.
\end{abstract}

\section{Introduction}

The state of world fisheries is alarming, with half of the global fish stocks reported as fully exploited and a further quarter as either overexploited or depleted (FAO 2007), reducing the long-term economic benefits derived from fishing (Clark 2006; Hilborn 2007). There is growing international consensus on the central role of the "race for fish" in the development of excess harvesting. The common-pool status of marine fish stocks leads to the existence of reciprocal negative

\footnotetext{
a Corresponding author: katell.hamon@ifremer. fr
}

externalities between fishing operators (Hardin 1968). These externalities entail a divergence between individually and socially optimal choices and the development of excess fishing capacity. Fishers tend to invest in more powerful and efficient fishing gear and techniques in order to stay in the race, leading to economic inefficiency, conflicts and social disruption and, in many cases, to the depletion of fish stocks beyond safe biological limits (Thébaud et al. 2007).

These difficulties are not new and have led to the development of fisheries management policies which can be broadly classified, according to their purpose, into two complementary sets of regulations (Troadec and Boncoeur 2003): (i) measures 
aimed at resource conservation and (ii) measures aimed at regulating the access to resources. To a large extent, fisheries management worldwide has rested exclusively on the first category of measures, at least initially. Although such regulations have proved indispensable, their effectiveness has been limited by the fact that they do not tackle the economic and institutional roots of excess capacity. Economic difficulties and conflicts have thus continued to develop, and resources are degraded despite the existence of conservation measures. In addition, the tense social climate resulting from excess capacity situations has often led to pressure being put on decision-makers to water-down conservation objectives themselves. Hence, many fisheries which have been conventionally managed for decades continue to show poor performances (Hilborn et al. 2003).

As stressed in the latest report on the state of world fishery resources published by the Food and Agriculture Organization of the United Nations (FAO 2007), there is growing recognition that the allocation of access rights to fisheries and fish resources is at the heart of sustainable fisheries management. Boncoeur et al. (2006) proposed a set of tools to regulate the individual access to fish stocks, including the use of incentivebased approaches resting on the definition of individual fishing rights (Hilborn 2007; Clark 2006; Grafton 1996). In particular, the implementation of Individual Transferable Quotas (ITQ) has been proposed as a regulation measure which can produce the incentives required for fishers to harvest fish stocks sustainably (Arnason 1990). Moloney and Pearse (1979) explain that fishers are expected to maximize profits within ITQ constraints, usually defined as shares of a given total allowable catch (TAC). The transferability of fishing rights would lead the most efficient fishers to buy additional quota shares from the least profitable fishing firms, thus reducing fishing capacity and improving the economic efficiency of fleets (Copes 1986; McCay 1995; Clark 2006).

Such a rationalization process may take several years, depending on alternative opportunities for vessels and crews (Campbell et al. 2000 and Grafton 1996) and on the degree of transferability of quotas (Dewees 1998), but it is expected to improve the overall profitability of fisheries and to reduce conflicts due to excess capacity. Increased profitability can also result from improvement in the market value of fish landed. A better market value, and hence a higher ex-vessel price received by fishers for their catch, can be achieved in different ways, e.g. fish quality improvement by i) the use of less damaging fishing gears (as expected for the Baltic Sea herring fishery in Kulmala et al. 2007), ii) on-board processing, and iii) the value of the catch, which can also be increased through price, if fishing occurs in seasons with high prices or if fishers can target fish categories fetching higher prices; see Annala (1996) for examples of fisheries implementing on-board processing and changing fishing seasons to fit the market.

A number of potential problems arising from the implementation of ITQ schemes have also been highlighted; see Copes (1986) for a comprehensive list of drawbacks of ITQ systems. Some of these difficulties relate to output-based controls. In particular, given individual catch constraints, fishers may choose to discard the less valuable fish caught in order to save their quota for more valuable fish (so-called high-grading), thus leading to increased catches and fishing

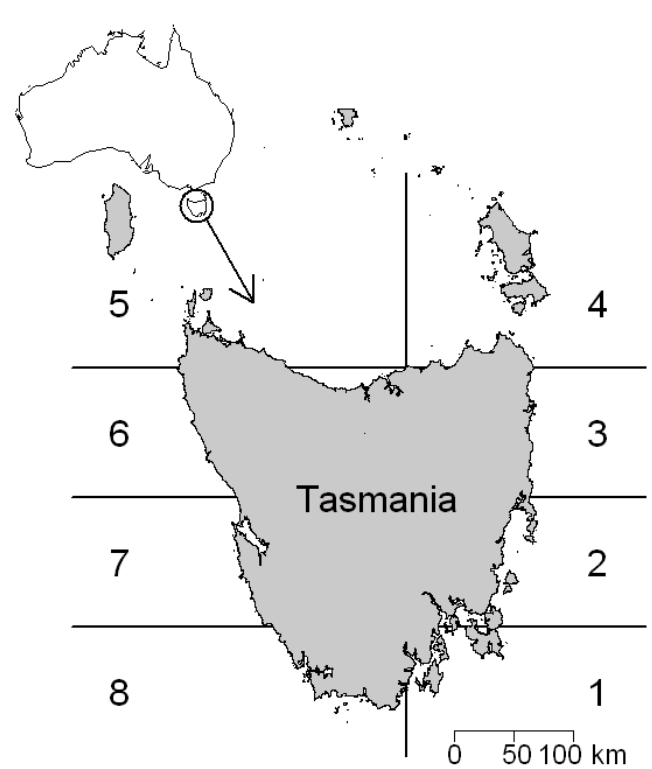

Fig. 1. Location of the Tasmanian red rock lobster fishery and the assessment areas.

mortality for given levels of landings. If undetected by catch monitoring systems, high-grading may lead to "data fouling", which in turns leads to less reliable stock assessments and the setting of TAC at unsustainable levels (Copes 1986). Other difficulties relate to the social implications of the changes in fisheries entailed by the adoption of ITQs, both in terms of reductions in employment (Copes 1986 and McCay 1995) and concentration of quota ownership. The latter has often led to the adoption of measures aimed at limiting the aggregation of quota shares (Dewees 1998). A key question which has also been largely debated in various contexts concerns the initial allocation of quota shares; see Arnason (2002) for an overview of the different allocation systems worldwide.

The fishery investigated in this paper is the Tasmanian red rock lobster fishery (Australia). The fishing fleet is composed of more than 200 vessels targeting red rock lobster (Jasus edwardsii) in the State coastal waters (Fig. 1) during the official fishing year from March to February, with a seasonal closure in October to protect males during moulting, and a ban on retaining females during the reproduction period from May to September. Red rock lobsters returned to the water after capture are considered to survive the fishing process. The fishery currently generates a gross revenue of about AUD 60 million at first sale (ABARE 2008). The employment related to the rock lobster industry in Tasmania was estimated at 1350 jobs in the early 2000s (Haddon and Gardner 2008). The TAC of 1523 tonnes in 2008 is caught with baited traps. Most red rock lobster caught in Tasmania is exported overseas (approximately 74\%, according to Bradshaw 2004) especially to the live Chinese market, where the fishery is a "price-taker" sensitive to Chinese prices. To match the Chinese market prices, processors practice split prices in the fishery, with red rock lobster categories depending essentially on two factors: size and colour. These factors are closely linked to the spatial distribution of effort based on two dimensions; the depth fished and the latitude. Red rock lobsters are caught in shallow waters (less 
than $40 \mathrm{~m}$ depth) whereas lobsters caught in deeper waters are "strawberry" to whitish in colour. The growth rate of red rock lobster is highly variable spatially, with a positive growth gradient from the southern to the northern regions of the State (Punt et al. 1997). The difference in growth results in a size gradient, with small rock lobsters in the south and bigger lobsters in the north. Due to the difference in growth rates, eight areas are modelled and assessed separately, despite a Statewide management (Fig. 1). Winter prices are also higher due to a decline of international supply of southern red rock lobster (mostly Australia and New Zealand; Annala 1996).

Tasmanian red rock lobster has been exploited for more than two hundred years and was first managed in 1889 with the "Fisheries Act", following a decline in rock lobster abundance (Winstanley 1973). Until 1967, only technical conservation measures were implemented, including gear restrictions, minimum landing size, seasonal closure and a ban on the harvesting of egg-bearing females. The sustainability of the stock remained questionable under those measures, which did not prevent a continuous increase of fishing effort. In an attempt to curb this effort, input restrictions were implemented from the late 1960s onwards, which capped the number of fishing licences and the number of traps used (Bradshaw 2004). Despite these input controls, catch and catch rates continued to decline in the fishery to a historically low level in 1994, and in 1996 the fishing industry voted in favour of an ITQ management system for the Tasmanian red rock lobster fishery, after several years of debate involving the industry, scientists and managers. The ITQ system was implemented in 1998, and the initial allocation was a particularly sensitive and strongly debated issue (Ford and Nicol 2001). The final allocation was primarily based on trap ownership, with a minor share of the quota allocation based on catch history in such a way that, during the first three years of the ITQ implementation, catch history accounted for $9 \%, 5 \%$ and $2 \%$ of the TAC. Individual catch history was set as the sum of the best three years from the period November 1988 to October 1997 (Ford and Nicol 2001). The 10507 quota units are currently worth $145 \mathrm{~kg}$ each. To limit aggregation of fishing rights, a 200 quota unit limit per quota owner was implemented (fishery rules, Anonymous 2005).

Based on a literature review, we identified the key effects expected from the implementation of ITQs in a fishery displaying excess capacity against which to confront the experience of the Tasmanian rock lobster fishery. We classified these expected effects in three broad categories:

- Fleet rationalization: following introduction of ITQs, less efficient vessels are expected to leave the fishery, leading to a decrease in overall costs of harvesting and to an increase in the economic efficiency of the fleet. Associated social consequences relate in particular to potential reductions in employment in the fishery (for examples of rationalization Annala 1996; Arnason 1996, 2002 and 2005 and Grafton 1996);

- Changes in harvesting strategies: these relate to the fact that fishers will seek to get the best value out of their individual allocation, which may entail high-grading and selection of areas, zones and fish targeted in order to land catches at the highest possible prices (Annala 1996; Arnason 2002 and Campbell et al. 2000);
- Concentration of landings and quota ownership: it has been observed in various contexts where ITQs have been adopted and is seen as a major social effect of such systems (Eythorsson 1996; Brandt 2005)

The objective of this paper is to examine the impacts of the adoption of ITQs in the Tasmanian fishery for red rock lobster (Jasus edwardsii) that have operated since 1998. Despite a growing number of papers describing the effect of ITQs all over the world, fairly few studies have analysed the retrospective economic impacts of the introduction of ITQs. Apart from the analysis of the halibut fishery in British Columbia by Casey et al. (1995), we are not aware of any similar analysis of the economic effects of ITQs in a fishery. We present a retrospective analysis of the effects of the adoption of ITQs, referring to the main expected effects of ITQ systems as they have been proposed and discussed in the literature: i) the rationalization of the fleet, ii) the change in fishing strategy and iii) the concentration of activity and quota ownership. Descriptive statistics for key variables were produced and simple indices calculated to measure changes in the status of the fishing fleet. Variables considered include vessel numbers and characteristics, fishing effort, landings and sale prices.

\section{Materials and methods}

\subsection{Data}

\section{Vessel data}

Information on fishing vessels was compiled from several databases. First, vessel characteristics since 2000 were collected from the database of the Department of Primary Industry and Water (DPIW), which manages Tasmanian natural resources. These characteristics include length, tonnage, construction type and the home port of the vessels. The second source of data was Marine and Safety Tasmania (MAST), a statutory authority responsible for the operational safety of recreational and commercial vessels of Tasmania. The MAST database included information on length, gross tonnage, construction year and horsepower for 2007. Information on vessel characteristics was used for 1997 and beyond.

\section{Catch-and-effort data}

The catch and-effort data analysed in this paper were extracted from the DPIW database, which consists of compulsory logbook data recorded daily by fishers since 1993. In addition to catch-and-effort data, various spatial and technical details concerning fishing trips are recorded in the database. The catch- and-effort time series were completed with monthly aggregated historical data available for the period 1970-1992.

\section{Price data}

The monthly ex-vessel price of rock lobster was derived from processor records, also collected by DPIW. Individual processors must inform the Department of the average monthly price at which they bought rock lobster from fishers and of the amount of lobster bought per month. The monthly price of 
rock lobster was thus calculated as the average price paid by individual processors weighted by the quantities of red rock lobster bought. Nominal prices (i.e. non-deflated) were used for the price analysis, while the Australian consumer price index was used to deflate the total value of the fishery using 2006 as reference year (source: Reserve Bank of Australia http://www.rba.gov.au).

\subsection{Retrospective analysis}

The retrospective analysis was carried out with the aim to assess the changes observed in the fishery with respect to the three broad categories of effects, namely, rationalization of the fleet, change in fishing strategies and concentration of activity and fishing rights. Analyses are based on the compilation of the different data sets describing the evolution of the status of the fishery over the last decade following implementation of the scheme.

\section{Analysis of the fleet}

The evolution of the fleet in terms of total number and composition was assessed through simple analysis of vessel characteristics. Length and tonnage were the only characteristics included in the analysis because of the quality of the coverage of the data, respectively 100 and $95 \%$ of vessels covered.

\section{Changes in fishing strategies}

Several factors affect the profit of the fishery: the operating costs, the fixed costs and the revenue generated from fishing. While fishers can hardly influence their fixed costs, they can seek profit maximization by decreasing their operating costs, depending on costs per unit of effort and effort, and increasing the revenue from fishing, which mostly depends on the price they received for their landings, given that the amount of rock lobster landed is fixed by their quota shares. Unfortunately, data were not available for costs which could not be included in the analysis of the evolution of fishing strategies. However, we did examine extensive time series and evolution of revenue through catch and price. Changes in fishing strategy were expected to occur with fishers seeking to maximise the return from their quota allocation due to the existence of market categories fetching different prices (Frusher et al. 2003 and Bradshaw 2004). The market categories of a rock lobster depend on several factors including (i) physical condition, (ii) colour and (iii) weight resulting in "split" prices, with "premium" lobsters with a rigid shell (i.e. not soft due to recent moulting), completely red in colour and weighing between 0.8 and $2 \mathrm{~kg}$, receiving up to 10 Australian dollars more per $\mathrm{kg}$ (C. Gardner, pers comm.). These characteristics are affected by spatial and temporal parameters, i.e. latitude, depth and season. To investigate potential changes in effort allocation related to premium prices, we compared the proportion of effort in the high-prices categories (premium size, shallow waters and winter) for periods of 5 years before (1993-1997) and after (20022006) introduction of the ITQ system.
Specific attention was devoted to rock lobster ex-vessel price, with the aim to assess whether sale prices for rock lobster had improved after the introduction of ITQs. The analysis was carried out using the Hodrick-Prescott (Hodrick and Prescott 1997) filter. This is used to identify long-term trends in time series by decomposing a time series $y_{t}$ as the sum of a trend component $\tau_{t}$ and a cyclical component $c_{t}: y_{t}=\tau_{t}+c_{t}$. The filter finds the $\tau_{t}$ that minimizes the following expression over the time series of length $T$ :

$$
\min _{\tau_{t}}\left(\sum_{t=1}^{T}\left(y_{t}-\tau_{t}\right)^{2}+\lambda \sum_{t=2}^{T-1}\left[\left(\tau_{t+1}-\tau_{t}\right)-\left(\tau_{t}-\tau_{t-1}\right)\right]^{2}\right)
$$

Two terms are identified in this expression. The first term constrains the cyclical component and the second constrains the trend component. The parameter $\lambda$ influences the strength of the penalty on the trend component. The lower the time step between observations, the higher $\lambda$ is in order to smoothen out the series. The data analysed in this paper are available at a monthly time step; the value for the $\lambda$ parameter used in the analysis is that recommended by Hodrick and Prescott (1997) for monthly data, i.e. 14400 .

\section{Evolution of activity and ownership concentration}

The evolution of concentrations of activity and fishing rights in the fishery was explored through methods commonly used in economics to measure inequity of wealth distribution, the Lorenz curve and the Gini index (Lorenz 1905 and Gini 1921).

\section{Results: the effects of adopting ITQs on the fishery}

The introduction of ITQs in 1998 involved the setting of a TAC which had not previously been implemented. The initial TAC was set at $1500 \mathrm{t}$, which was lower than the pre-ITQ catch. In 2002, the TAC was raised to $1523 \mathrm{t}$ (Haddon and Gardner 2008).

Prior to the introduction of ITQs, total effort and catch increased mainly as a result of fishers building catch history, while discussions went on regarding the implementation of the scheme. This is supported by the reduction of effort in the summer (November to February) of 1997, five months prior to the introduction of the quota management scheme, which was not taken into account in the definition of catch history.

Fishing effort continued to decrease after the introduction of quotas, in the absence of further regulations on the input side (Fig. 2). Following adoption of the TAC, and the capping of catch at a constant level, the stock has been rebuilding. This has contributed to an increase in average catch rates (Fig. 2), as in 2006/2007 fishers used $20 \%$ less trap-lifts to catch the TAC than in 1998/1999 (Haddon and Gardner 2008). 
Table 1. Number of fishing vessels per length class.

\begin{tabular}{crrrrrrrrrr}
\hline Length class & 1997 & 1998 & 1999 & 2000 & 2001 & 2002 & 2003 & 2004 & 2005 & 2006 \\
\hline$\leqslant 10 \mathrm{~m}$ & 39 & 28 & 18 & 12 & 10 & 10 & 10 & 9 & 8 & 6 \\
$10-18 \mathrm{~m}$ & 271 & 244 & 225 & 217 & 214 & 208 & 207 & 202 & 199 & 193 \\
$>18 \mathrm{~m}$ & 15 & 15 & 12 & 13 & 15 & 17 & 17 & 21 & 18 & 15 \\
Total & 325 & 287 & 255 & 242 & 239 & 235 & 234 & 232 & 225 & 214 \\
\hline
\end{tabular}

Table 2. Contribution of length class to the total physical capacity of the fleet (gross tonnage) in percent.

\begin{tabular}{crrrrrrrrrrr}
\hline Length class & 1997 & 1998 & 1999 & 2000 & 2001 & 2002 & 2003 & 2004 & 2005 & 2006 \\
\hline$\leqslant 10 \mathrm{~m}$ & 3 & 3 & 2 & 2 & 1 & 1 & 1 & 1 & 1 & 1 \\
$10-18 \mathrm{~m}$ & 84 & 81 & 85 & 84 & 83 & 83 & 83 & 79 & 82 & 83 \\
$>18 \mathrm{~m}$ & 13 & 16 & 13 & 14 & 16 & 16 & 16 & 20 & 17 & 16 \\
\hline
\end{tabular}

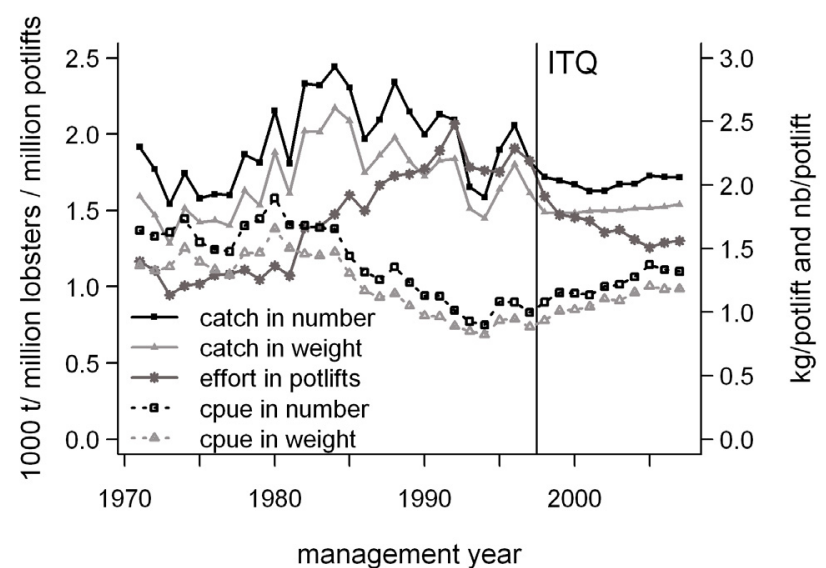

Fig. 2. Annual trend in effort, catch and catch rates in Tasmanian red rock lobster fishery.

\subsection{Changes in the fishing fleet}

\section{Rationalization of the fleet}

As expected, the size of the fishing fleet was reduced by $25 \%$, from 325 to 242 vessels, in the first three years of quotabased management (Table 1). It then stabilized around 240 vessels until 2004 before a further decline, with the latest estimate of the fleet size being 214 vessels in 2006 . The number of traps used by fishers is regulated and the amount of traps allowed onboard varies from 15 to 50, depending on the size and gross tonnage of the vessel (Anonymous 2005).

\section{Characteristics of the vessels}

The size composition of the fleet did change over the years, as expected. Most vessels measure between 10 and $18 \mathrm{~m}$ in length (Table 1), with the number of vessels in this fleet segment rising from $83 \%$ of the total fleet in 1997 to $90 \%$ in 2000 . Most of the vessels less than 10-m long left the fishery in the first three years of quota: from the 39 vessels catching rock lobster in 1997 only a third remained in 2000. The number of the bigger vessels $(>18 \mathrm{~m}$ ) in the fleet remained the same, with 15 vessels in 2006 as in 1997 and even increased up to 21 in 2004. The evolution of the structure of the fleet can also be considered in terms of contribution of size classes to the capacity of the fleet (gross tonnage), which was reduced more strongly for the small vessels as shown in Table 2. While most of the fleet's capacity has been composed of vessels between 10 and $18 \mathrm{~m}$ and remained consistent at around $80 \%$ of the fleet capacity, the proportion of capacity for bigger vessels has varied, from $13 \%$ of fleet's total tonnage in 1997 to $20 \%$ in 2004 and $16 \%$ in 2006 (Table 2).

This evolution of the size distribution of vessels could be related to the development of winter fishing for the Asian market in the early 1990s, which led to the construction of bigger vessels, more suitable for rougher winter and west coast seas. It is also likely that the carrying limit of traps on board influenced this distribution. Indeed, only vessels longer than $18 \mathrm{~m}$ and bigger than $30 \mathrm{t}$ are allowed to carry the maximum of 50 traps.

\subsection{Changes in fishing strategy}

\section{Seasonal distribution of fishing activity}

Like all crustaceans, red rock lobsters exhibit discontinuous growth in size by periodic moulting. During the first stages of moulting, when the carapace is extremely soft, lobsters remain in dens and do not feed. The combined stress of moulting and fasting lowers the condition of the rock lobsters. The end of the moulting period in November was historically the beginning of the fishing season: once the exoskeleton begins to harden, rock lobsters are highly catchable as they attempt to replenish their food reserves. However, those rock lobsters are in poor physical condition, and processors are often reluctant to purchase them because of the large mortality rates suffered during shipment to the Asian market. Softer lobsters are thus normally retailed on the domestic market at lower prices.

The proportion of fishing effort allocated to the winter season increased after the introduction of ITQs from a median value of 39 to $46 \%$ of effort allocated to winter months (Fig. 3). Fishers' response to the new regulation was extremely fast, and it may have been facilitated by the change which occurred in the regulatory dates of the management year. Managers decided to set the official fishing season from March to February and opened fishing in September (but kept the seasonal closure in October for the moult), instead of the traditional fishing season from November to August to encourage fishing in winter (April to September) when prices are high. Indeed, keeping quota for winter would have been risky, as catch rates are lower 


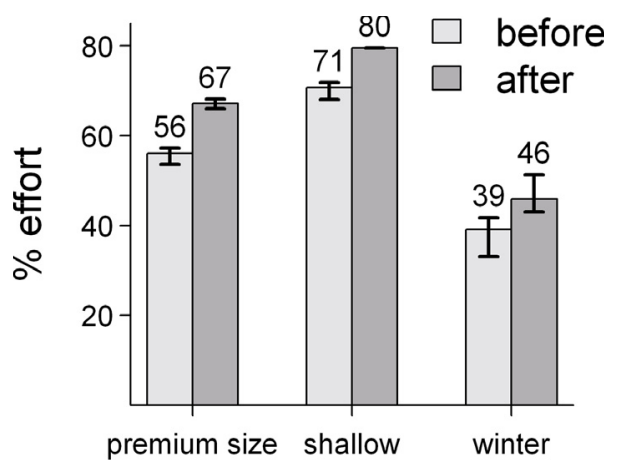

Fig. 3. Proportion of effort resulting in catch of red rock lobster of premium depth, season and size; the height noted above the bars represents the median, and the whiskers the min and max non-outlier values. Before and after periods are respectively 1993-1997 and 20022006.

and weather conditions can prevent fishers from going out to sea. With the current fishing season starting in March, fishers can plan their fishing calendar without fear of having a portion of their quota uncaught at the end of the season. The variability of the seasonal fishing allocation is relatively high due to the fact that fishers are opportunistic and can change their fishing plans depending on weather conditions or if winter prices are not as high as expected (this happened during the severe acute respiratory syndrome (SARS) outbreak. Despite a high variability in the proportion of winter allocation, it should be noted that there is no overlap of the error bars between the before and after periods (Fig. 3).

\section{Fishing depth}

The colour of rock lobster depends on the depth of its habitat. In shallow waters (less than $40 \mathrm{~m}$ ) the rock lobster is uniformly bright red. In depths greater than $40 \mathrm{~m}$, rock lobsters become paler and their appearance is speckled. Following introduction of individual quotas, the proportion of fishing effort in shallow waters tended to increase, most probably due to a targeting of these premium rock lobsters (Fig. 3); before 1998 , around $70 \%$ of trap-lifts were made in shallow waters and this proportion increased to $80 \%$ in the 2002-2006 period. This change in effort allocation to shallow waters also allowed reduction in steaming time, and therefore fuel costs.

\section{Lobster size}

The fishing strategy regarding the size of targeted rock lobsters was calculated as the average lobster size per trip (total weight of lobster caught divided by their number). Before 1998 , the proportion of trips with average lobster size in the premium size range $(0.8$ to $2 \mathrm{~kg}$ ) was slightly above $55 \%$, while the proportion of trips with premium average size has grown to around 67\% of total effort since 1998 (Fig. 3). Three factors might have led to the increase of average size of lobsters, (i) a lack of smaller lobsters in the north of the state, where fishers and scientists have observed a decline in lobster recruits in the past few years (Haddon and Gardner 2008); (ii) animals left in the water growing further, increasing the

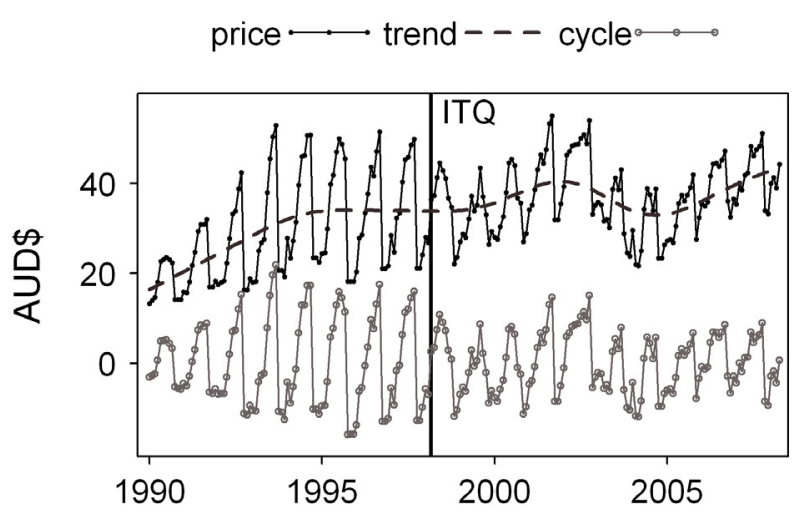

Fig. 4. Hodrick-Prescott filter of monthly ex-vessel prices of Tasmanian red rock lobster.

proportion of big lobsters in the water resulting from the rebuilding of the stock, and (iii) fishers targeting specific sizes. It is likely that all these factors combined are partly responsible for the increase in premium size in the landings. However, no trend could be identified in the average size of lobster in each management area (Fig. 1), suggesting that the targeting of specific size classes is probably the main factor affecting average size in landings.

Contrary to expectations, there was no clear evidence that high-grading has increased in the rock lobster fishery after the introduction of individual quotas, and discards have been assumed to have remained constant over the period. This was checked against the new data system whereby fishers record the number of lobsters put back in the water, and very little discard was recorded. The only high-grading that occurs is the discarding of big lobsters (more than $2 \mathrm{~kg}$ ) because the beach price of those lobster is much lower than for any other size category, and this only occurred since 2004, when the cost of leasing quota increased over AUD 20 per kg. However, discarding has never been an issue in this fishery because lobsters are released alive in the water causing no or very little mortality. Fishers can also target particular sizes by setting their pots at different latitudes (there is a south-north positive growth gradient in the Tasmanian rock lobster population).

\section{Consequences on ex-vessel prices and gross returns}

Most Tasmanian rock lobster is exported to the Asian live lobster market (Bradshaw 2004). The beach price of rock lobster is therefore highly influenced by the Chinese market and exchange rates. The trend line computed with the HodrickPrescott filter applied to the nominal ex-vessel prices (Fig. 4) shows an increase in lobster price in the early 1990s corresponding to the development of exports of live Tasmanian rock lobster to Asian markets. The decline observed in 2003 is due to the SARS episode in Asia which affected tourism and, as a result, decreased the demand for high-value food products on Asian markets (Harcourt 2003).

Because of this incident, it is difficult to clearly identify at the scale of the study period the long-term effect of ITQs on beach price for lobster, which could be expected from the changes in the composition of landings. However, in the first few years following the introduction of ITQs, the trend price 


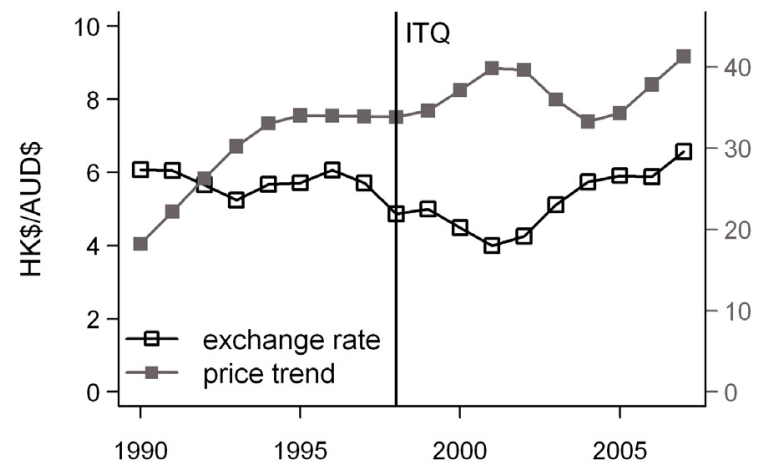

Fig. 5. Exchange rate and Hodrick Prescott price trend.

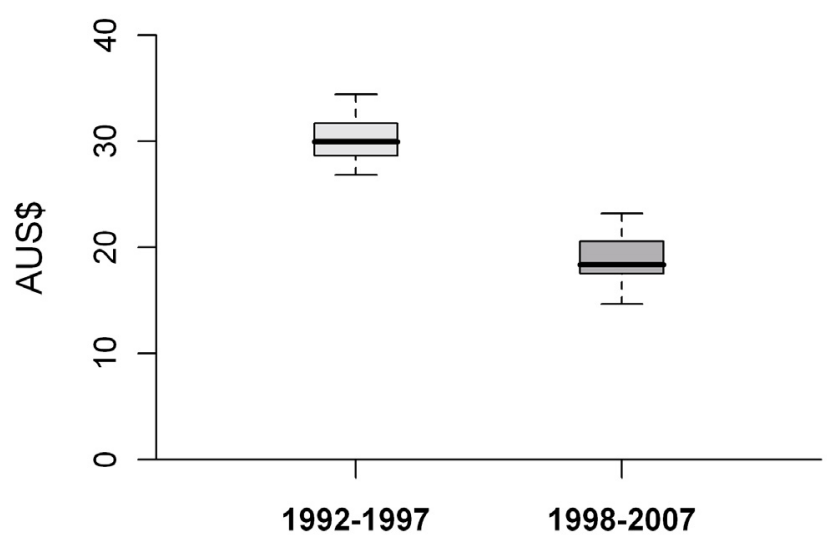

Fig. 6. Variability of price cycle.

increased from around AUD 34 per kg (1995-1997) to more than AUD 40 per $\mathrm{kg}$ in 2002 in nominal (non-deflated) terms. The exchange rate with Hong-Kong is certainly the most important factor influencing the average ex-vessel prices, even though there is some inconsistency at the end of the time series (Fig. 5). The price trend followed the exchange rate as a mirror image, except for the few years after the SARS crisis (2005-2007); during these years, lobster price continued growing despite an increasing exchange rate (Fig. 5).

The seasonal redistribution of effort explains the strong change observed in the intra-annual price variability for lobster, shown by the cyclical pattern (Fig. 6). The variability of ex-vessel prices (i.e. the difference between the annual maximum and minimum price) decreased from around AUD 30 before 1998 to less than AUD 20 after 1998. Overall, and excluding the SARS episode, winter prices are not as high as before the introduction of ITQs, and summer prices are not as low either and the intra-annual price variability has been significantly reduced (Fig. 6). Higher summer prices are probably related to a decrease in soft-shell landings in November.

The consequences of the price variation in terms of the total value of rock lobster catch can be estimated on the basis of the product of the monthly catch and the average monthly beach price (Fig. 7). To analyse the evolution of the value of lobster catch, we consider deflated prices and correct gross value by the Australian consumer price index (CPI) relative to $2006\left(\mathrm{CPI}_{2006}=1\right)$. The TAC, set in 1998 , was below the

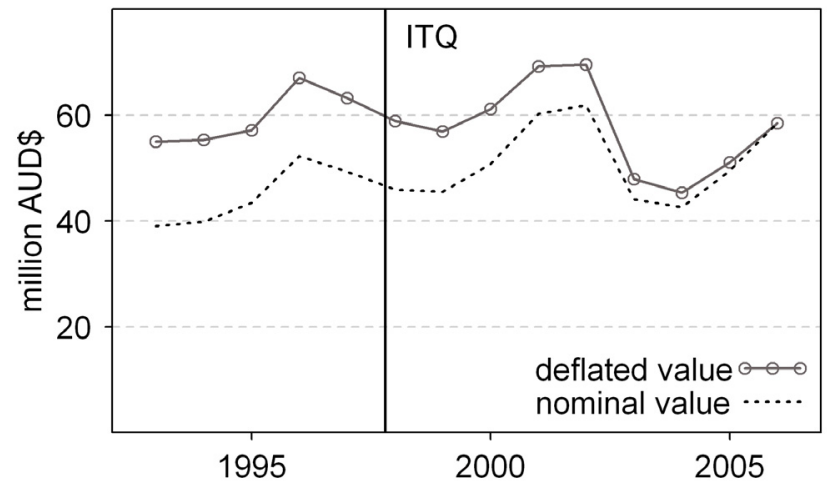

Fig. 7. Evolution of the total nominal and deflated value of Tasmanian red rock lobster catch.

pre-ITQ catch and resulted in a decline in the total value of the fishery in 1998 and 1999. The large increase in nominal value of the catch in the following years (2000-2002) is a result of an advantageous exchange rate (Fig. 5). The drop observed for the following years derived from the decrease in the price of lobster due to SARS as the quantity landed did not change. However, the last increase in total value (2005-2006 on Fig. 7) cannot be explained by the exchange rate (Fig. 5), as the increasing exchange rate would have had the opposite effect. The individual quality of rock lobsters is most likely to be the cause of the large increase in gross value product for the period 2005-2006. The deflated gross value of the fishery in 2006 is around the same level as at the introduction of ITQ in 1998 despite the SARS accident (Fig. 7).

\subsection{Concentration of rights and activity.}

Concentration of quota was not regarded as a potential issue in the Tasmanian rock lobster fishery because the aggregation limit per quota owner was set relatively low (2\% of the TAC, Anonymous 2005). This is confirmed when looking at the concentration profile of ownership (Fig. 8a). As expected from the theory, the distribution of quota shares in the fishery was less equitable in 2006 than the initial allocation in 1998 but the Gini index, which is commonly used as a measure of the inequity of distribution (Gini 1921), remained at a fairly low level (0.36 in 2006). The extremely low level of the Gini index at initial allocation $(0.20)$ proves that the extensive debate prior to implementation of the management scheme led to an equitable repartition of fishing rights amongst industry participants. It should be noted than the number of owners is almost the same in 2006 as in 1998 (respectively 292 and 291) and that the number of quota owners remained stable over the period.

The concentration of activity, however, has not changed. Despite a major decrease of the number of vessels in the fishery, the catch (and therefore the TAC) has been distributed evenly amongst the remaining operators and the distribution of activity has been maintained at a relatively constant level (Fig. 8b); this was also assessed by looking at the evolution of Gini indices. Catch distribution exhibit low Gini index (around $0.35)$, suggesting a rather homogeneous distribution of catch 

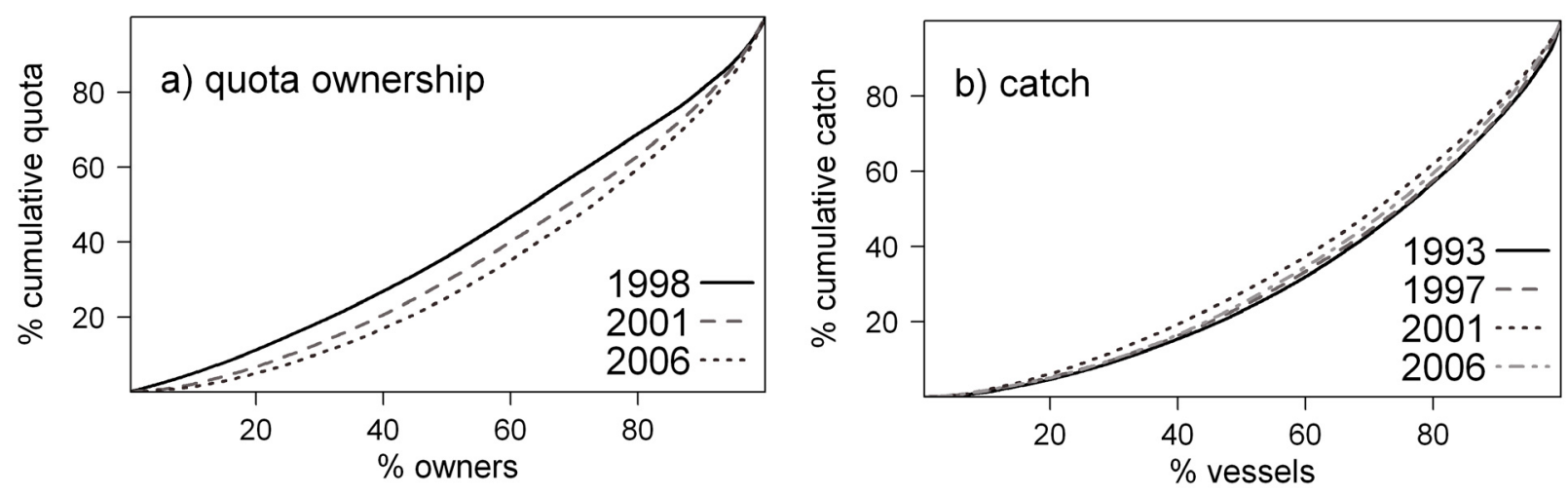

Fig. 8. Concentration profiles of (a) quota ownership and (b) catch by vessel.

in the fishery. No change can be identified in the evolution of the index, the concentration of catches having apparently remained stable as the overlapping curves on Fig. $8 \mathrm{~b}$ suggest. We could have expected a distribution of effort 'flatter' after 1998 as the less active vessels were expected to have left the fishery but it seems that there were still fishers with low catches operating in the Tasmanian rock lobster fishery in 2006.

\section{Discussion - Conclusion}

The studies and debates over ITQs are still dividing scientists, and the management system once presented as the ideal management tool for sustainable fisheries is now considered as a very efficient scheme under certain given conditions. Grafton and McIlgorm (2009) defined a formal framework for ex-ante evaluation of a fishery before introduction of ITQs, based on five criteria to ensure that the conditions for a successful ITQ system were satisfied.

The Tasmanian rock lobster fishery would have passed the five criteria they proposed. Firstly, the gross value of production (GVP) was twenty times higher than the AUD 2 million threshold they chose which could support the additional costs related to management. Secondly, the rock lobster fishery is a single-species fishery with very little by-catch, satisfying the targeting ability required. Thirdly, the number of vessels in the fishery was relatively small (just over 340 in 1993) but high enough to allow competition in quota trading. Fourthly, there is the ability to get premium products through seasonal and spatial redistribution of effort as discussed extensively in this paper and, finally, the variability of the stock recruitment relationship is rather low relative to harvest-effort relationship (Haddon and Gardner 2008). As a result, the Tasmanian rock lobster fishery would have been considered a very good candidate for ITQs as are most fisheries with high-value products (McIlgorm and Tsamenyi 2000).

ITQ was introduced in the Tasmanian rock lobster fishery as an attempt to limit the pressure on the stock and stop the decline in biomass. According to the 2008 fishery assessment report (Haddon and Gardner 2008), the management system has been successful, with exploitable biomass doubling since historical low record in 1994. The expected impacts on the fishery identified in the literature were largely observed in the Tasmanian rock lobster fishery, and fishers mostly behaved as anticipated by the managers. The decrease of the fleet capacity and of fishing effort relieved the pressure on the stock, which rebuilt over the period. The decrease of effort should be related to operating costs and, even though the time series of costs was not available, the decrease of fishing effort by $30 \%$ between 1997 and 2006 can be compared to the $28 \%$ increase of CPI over the same period, which can be taken as a proxy for operating costs. The number of vessels operating in the fishery decreased dramatically by $25 \%$ during the first three years of quota and further until the current size, slightly over 200 vessels, i.e. $60 \%$ of the initial fleet. The fishing vessels were mostly made out of timber and sold as leisure sailing boats because most valuable fisheries around Tasmania had been locked down with a similar limited-entry scheme by the time ITQs were implemented for rock lobster (Frusher et al. 2003). The total fixed costs of the fishery are positively related with the size of the fishing fleet. Although mostly smaller vessels left the fishery, it can be assumed that, given the large amount of vessels leaving, at worse the total fixed costs of the fishery remained stable and they might even have decreased slightly.

The overall assessment of the fishery in terms of profit is not very conclusive. The total profit of the fishery is likely to have remained stable over the period when taking the inflation into account, but owner-operators are probably better off because fewer of them are sharing this profit. As Frusher et al. (2003) observed by interviewing fishers in the industry, the situation of leasers is more complex because the profit is then shared between the owner of the quota share and the fisher through leasing price. Fishers have adapted their fishing behaviour to maximize the return per $\mathrm{kg}$ of rock lobster. The analysis of the data confirms what Frusher et al. (2003) had identified as emerging behaviours through interviews. Fishers chose to reallocate their effort, both spatially and temporally, towards more valuable lobsters for export to Asia. This new fishing strategy has had a direct effect on the gross value of the fishery which, despite the SARS accident, has been growing against the exchange rate for last few years of the period studied.

While the Tasmanian rock lobster industry is satisfied by the ITQ system (Treloggen, Tasmanian Rock Lobster Fishermen's Association's executive officer, pers. comm.), the change in fisher's behaviour brought about by the ITQ system has focused attention on the need for improved spatial 
management of the fishery to ensure productivity from optimal harvest regions.

The implementation of an ITQ system has had an overall positive impact in the Tasmanian rock lobster fishery. However, given how well it satisfied the required conditions stated in Grafton and McIlgorm (2009), the results can be disappointing. The global trend in fisheries management still focuses towards right-based management which is currently being intensively discussed in the European Union as future common policy. The lessons learned from the Tasmanian case study show that, even if the fishery behaves in an expected way, unexpected external perturbations can greatly impact the performances of such a system.

Acknowledgements. The first author is supported by a PhD scholarship co-funded by IFREMER and the joint CSIRO-UTAS Quantitative Marine Science program (QMS). We thank Muriel Travers for her assistance with respect to the analysis of price variations and Caleb Gardner for providing the latest data. We would also like to thank an anonymous reviewer and Serge Garcia for valuable comments which helped improve this manuscript greatly.

\section{References}

ABARE, 2008, Australian Fisheries Statistics 2007. Australian Bureau of Agricultural and Resource Economics, Canberra. [online] http://www.abareconomics.com/publications_html/ fisheries/fisheries_08/08_fishstats.pdf

Annala J.H., 1996, New Zealand's ITQ system: have the first eight years been a success or a failure? Rev. Fish Biol. Fish. 6, 43-62.

Anonymous, 2005, Draft Fisheries (Rock lobster) Rules 2005. Tasmanian Parliament. [online] http://www.dpiw.tas.gov.au/ inter.nsf/Attachments/HMUY-6FE75R/\$FILE/rocklobster_ DRAFT_rules.pdf

Arnason R., 1990, Minimum information management in fisheries. Can. J. Econ. 23, 630-653.

Arnason R., 2002, A review of international experiences with ITQs: an annex to Future options for UK fish quota management. CEMARE Rep. No. 58.

Arnason R., 2005, Property rights in fisheries: Iceland's experience with ITQs. Rev. Fish Biol. Fish. 15, 243-264.

Boncoeur J., Guyader O., Thébaud O., 2006, A typology of fisheries management tools. AMURE Working Pap. Ser. [online] http://www.univ-brest.fr/gdr-amure/documents/gdr-amure-D16-2006.pdf

Bradshaw M., 2004, A combination of state and market through ITQs in the Tasmanian commercial rock lobster fishery: the tail wagging the dog? Fish. Res. 67, 99-109.

Brandt S., 2005, The equity debate: distributional impacts of individual transferable quotas. Ocean Coast. Manage. 48, 15-30.

Campbell D., Brown D., Battaglene T., 2000, Individual transferable catch quotas: Australian experience in the southern bluefin tuna fishery. Mar. Policy 24, 109-117.

Casey K.E., Dewees C.M., Turris B.R., Wilen J.E., 1995, The effects of individual vessel quotas in the British Columbia halibut fishery. Mar. Resour. Econ. 10, 211-230.
Clark C.W., 2006, The worldwide crisis in fisheries. Economic models and human behavior. Cambridge University Press.

Copes P., 1986, A critical review of the individual quota as a device in fisheries management. Lands Econ. 62, 278-291.

Dewees C.M., 1998, Effects of individual quota systems on New Zealand and British Columbia fisheries. Ecol. Appl. 8, 133-138.

Eythorsson E., 1996, Theory and practice of ITQs in Iceland Privatization of common fishing rights. Mar. Policy 20, 269-281.

FAO 2007, The State of World Fisheries and Aquaculture - 2006 (SOFIA). Food and Agriculture Organization of the United Nations, Rome.

Ford W., 2001, Case studies on the effects of transferable fishing rights on fleet capacity and concentration of quota ownership. In: Shotton R. (Ed.), Case studies on the effects of transferable fishing rights on fleet capacity and concentration of quota ownership,. FAO Fish. Tech. Pap. Rome, 412, pp. 112-123.

Ford W., Nicol D., 2001, The initial allocation of Individual Transferable Quotas in the Tasmanian rock lobster and abalone fisheries. In: Shotton R. (Ed.),Case studies on the allocation of transferable quota rights in fisheries, FAO Fish. Tech. Pap. Rome, 411, pp. 171-186.

Frusher S., Eaton L., Bradshaw M., 2003, Impact of management change to an ITQ system in the Tasmanian rock lobster fishery. Tasmanian Aquaculture and Fisheries Institute. University of Tasmania, FRDC Final report, 1999/140.

Grafton R.Q., 1996, Experiences with individual transferable quotas: An overview. Can. J. Econ. 29, 135-138.

Grafton R.Q., McIlgorm A., 2009, Ex-ante evaluation of the costs and benefits of individual transferable quotas: A case-study of seven Australian commonwealth fisheries. Mar. Policy 33, 714-719.

Gini C., 1921, Measurement of inequality of incomes. Econ. J. 31, 124-126.

Haddon M., Gardner C., 2008, Tasmanian rock lobster fishery 2006/2007. Fishery Assessment Report, Tasmanian Aquaculture and Fisheries Institute, University of Tasmania.

Harcourt T., 2003, The economic effects of SARS: what do we know so far? Australian Trade Commission. [online] http://www.austrade.gov.au/The-economic-effects-of-SARSwhat-do-we-know-so-far-/default.aspx.

Hardin G., 1968, Tragedy of the Commons. Science 162, 1243-1248.

Hilborn R., Branch T.A., Ernst B., Magnussson A., Minte-Vera C.V., Scheuerell M.D., Valero J.L., 2003. State of the world's fisheries. Ann. Rev. Environ. Resour. 28, 359-399.

Hilborn R., 2007, Managing fisheries is managing people: what has been learned? Fish Fish. 8, 285-296.

Hodrick R.J., Prescott E.C., 1997, Postwar US business cycles: an empirical investigation. J. Money Credit Banking 29, 1-16.

Kulmala S., Peltomaki H., Lindroos M., Soderkultalahti P., Kuikka S., 2007, Individual transferable quotas in the Baltic Sea herring fishery: A socio-bioeconomic analysis. Fish. Res. 84, 368-377.

Lorenz M.O., 1905, Methods of measuring the concentration of wealth. Publ. Am. Stat. Assoc. 9, 209-219.

McCay B.J., 1995, Social and ecological implications of ITQs: an overview. Ocean Coast. Manage. 28, 3-22. 
McIlgorm A., Tsamenyi M., 2000, Rights-based fisheries development in Australia; has it stalled? In: Shotton R. (Ed.) Use of property rights in fisheries management. Proc. FishRights99 Conference. Fremantle, Western Australia, 11-19 Nov. 1999, FAO Fish. Tech. Pap. Rome, 404/2, pp. 148-154.

Moloney D.G., Pearse P.H., 1979, Quantitative rights as an instrument for regulating commercial fisheries. J. Fish. Res. Board Can. 36, 859-866.

Pecl G., Frusher S., Gardner C., Haward M., Hobday A., Jennings S., Nursey-Bray M., Punt A., Revill H., van Putten I., 2009, East coast, Tasmania, an assessment of climate change impacts on east coast rock lobster productivity, interactions with fisheries management and flow-on effects to local communities. Case study to support a 'first pass' National Climate Change Coastal Vulnerability Assessment (NCVA). Rep. Dep. Climate Change.
Punt A.E., Kennedy R.B., Frusher S.D., 1997, Estimating the sizetransition matrix for Tasmanian rock lobster, Jasus edwardsii. Mar. Freshwater Res. 48, 981-992.

Thébaud O., Boncoeur J., Berthou P., 2007, Regulating access to marine fisheries in the coastal zone: key issues. AMURE working Pap. Ser. D22-2007 [online] http://www.univ-brest.fr/gdr-amure/ documents/gdr-amure-D-22-2007.pdf

Troadec J.P., Boncoeur J., 2003, La régulation de l'accès. In : Laubier L. (coord.), Exploitation et surexploitation des ressources marines vivantes. Académie des Sciences, Rapp. Science Technologie, Lavoisier, Tec \& Doc, Paris, pp. 355-393.

Winstanley R., 1973, Rock lobster fishing in Tasmania, 1904-1972. Tasmanian Fish. Res. 7, 1-23. 